\title{
ON THE METAPLEURAL GLAND OF ANTS
}

\author{
By Bert Hölldobler and Hiltrud Engel-Siegel \\ Department of Organismic and Evolutionary Biology, \\ MCZ-Laboratories, Harvard University \\ Cambridge, Massachusetts
}

\section{INTRODUCTION}

The metapleural gland (also called metasternal or metathoracic gland), a complex glandular structure located at the posterolateral corners of he alitrunk is peculiar to the ants. Although the gland was noted by Meinert (1860) and Lubbock (1877), it was Janet (1898) who conducted the first detailed anatomical study of this organ, as part of his classic work on Myrmica rubra. Additional details have been added by Tulloch (1936) on Myrmica laevinodis; by Whelden (1957a, b, 1960, 1963) on Amblyopone (Stigmatomma) pallipes, Rhytidoponera convexa, $R$. metallica, Eciton burchelli, E. hamatum; by Tulloch et al (1962) on Myrmecia nigrocincta; and by Kürschner* (1970) on Formica pratensis.

It is generally assumed that the metapleural gland is a universal and phylogenetically old character of the Formicidae. Even the extinct species Sphecomyrma freyi of Cretaceous age appears to have possessed a metapleural gland (Wilson et al 1967a, b) and the organ is well developed in the most primitive living ant species Nothomyrmecia macrops (Taylor 1978) (see Fig. 2).

In the course of our current comparative study of the internal and external anatomy of exocrine glands in ants, we discovered that the metapleural gland is absent or significantly reduced in several ant genera where such reduction had not been previously suspected. In addition we observed a widespread absence of the metapleural gland in males among ant species.

Our survey is far from complete, even at the generic and tribal levels. We think, however, that the pattern revealed by our observations is important enough to warrant a short publication at this time.

\footnotetext{
*Kürschner apparently was not aware that the paired thorax gland near the petiole she described was the metapleural gland.

Manuscript received by the editor March 16, 1984.
} 


\section{RESULTS}

The metapleural gland is a paired structure. Each side consists of a cluster of glandular cells, and each cell is drained via a duct into a membranous collecting sac that Tulloch et al. (1962) called secretory recess. The collecting sac leads directly into the storage chamber or atrium (receptacle, sensu Tulloch et al. 1962), a sclerotized cavity. Externally the metapleural gland is often marked by a pronounced vault (bulla), and a slit-shaped opening to the outside (Fig. 1).

Although the metapleural gland is present in most ant species, it nevertheless varies greatly among them in size and shape (Figs. $2 \&$ 3). Table 1 lists all of the ant species for which we obtained complete series of longitudinal sections through the mesosoma. The specimens were fixed in alcoholic Bouin or Carnoy, embedded in methylmethacrylate and sectioned 6 to $8 \mu$ thick. The staining was Azan (Heidenhain). We attempted to obtain approximations of the number of glandular cells either by counting the cells with clearly visible nuclei or by counting the number of duct openings in successive sections.

The data reveal a considerable variation in the size of the metapleural gland among different species. Even more significantly, our study established that the gland is absent in Oecophylla longinoda and O. smaragdina (Fig. 4), in all species of Camponotus and Polyrhachis sectioned, and in Dendromyrmex chartifex (Tab. 1).

We extended this list by an additional survey of the external features that indicate the presence of the metapleural gland, using light-stero-, and scanning electrone microscopy. Of 27 species of Camponotus investigated, only $C$. gigas showed a slit-shaped opening in the posterior metapleural region (Fig. 5c). In all other Camponotus species the metapleural gland is clearly absent (Fig. 5a, b; Tab. 2). This confirms the suggestion of Ayre and Blum (1971) based on external inspection of Camponotus pennsylvanicus workers that this species might not possess a metapleural gland. In none of the species of Polyrhachis investigated did we detect any signs of a metapleural gland (Tab. 2). In addition our study revealed that in several species whose workers and queens have welldeveloped metapleural glands, the males do not possess this organ; whereas in other species the males have large metapleural glands (Tab. 1). 

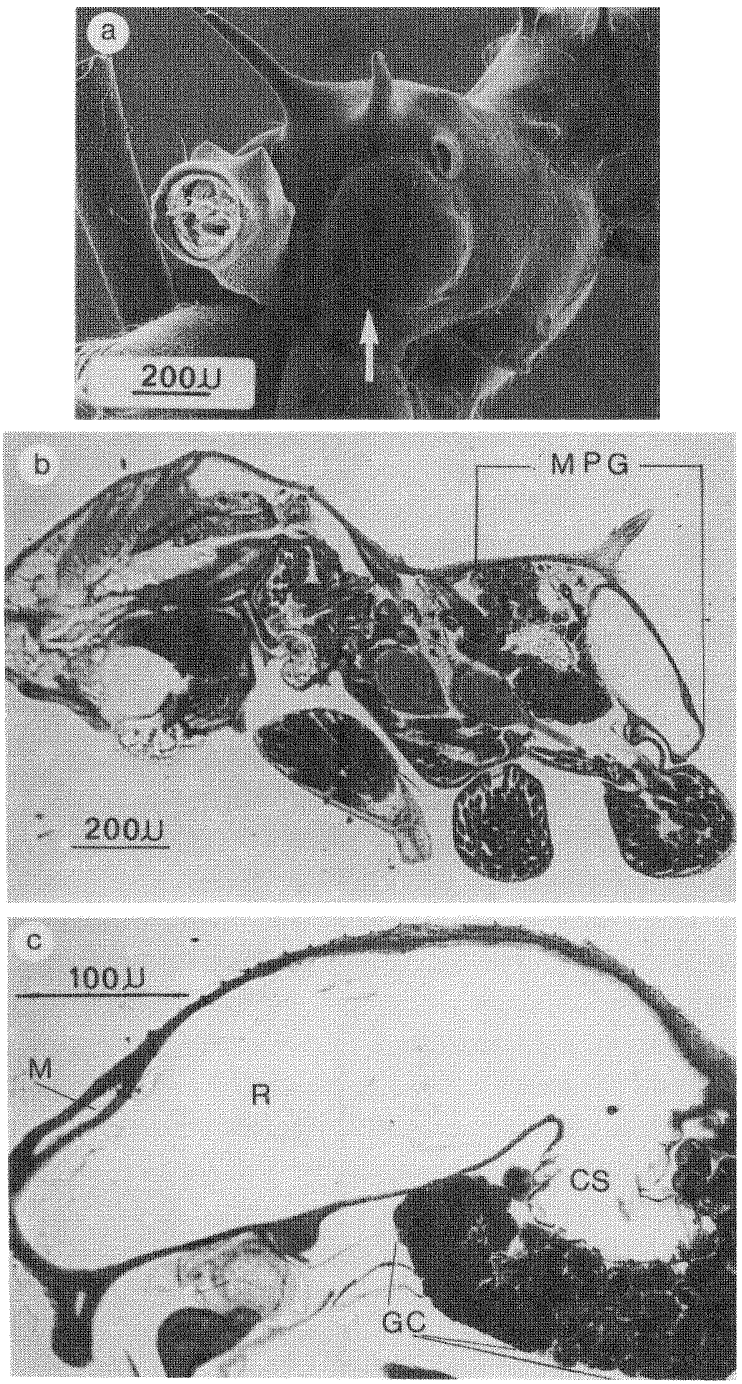

Fig. 1. The metapleural gland of Alla, illustrating the major anatomical feature of this organ. a. SEM micrograph of the mesosoma of $A$. c'ephalotes, showing the large pronounced vault (bulla) which covers the storage chamber. Arrow points to the slit-shaped opening (meatus). b. Longitudinal section through the mesosoma of $A$. sexdens, showing the large region of the metapleural gland (MPG). c. Longitudinal section through metapleural gland: $C S=$ collecting sac; $G C=$ glandular cells; $\mathbf{M}=$ meatus; $\mathbf{R}=$ storage chamber or receptacle. 


\section{Discussion}

The metapleural glands have been considered characteristic of all ants with the very few exceptions given by Brown (1968). From a survey of external criteria Brown listed four categories where the metapleural gland appears to be atrophied: "1. Males of army ants, subfamily Dorylinae. 2. Males of a few other genera, mainly in subfamily Myrmicinae (e.g. Leptothorax duloticus, Tetramorium, Strongylognathus, Rhoptromyrmex, Huberia striata). 3. Workers of the specialized slave makers of genus Polyergus. 4. Queens of certain scattered ant species that are known (or assumed, on grounds of other morphological peculiarities) to be social parasites, i.e., those species which found their colonies in the nests of other ant species". From these findings Brown developed an intriguing hypothesis about the function of the metapleural gland: "the gland produces a substance that, when tasted or smelled, says to another ant colony, especially one of the same species, 'I am an enemy'." According to Brown's hypothesis "an individual either with the same odor-or-taste, or with none at all, would be treated by its host colony as neutral". This would explain why certain species whose individuals have to enter a foreign colony (social parasites; doryline males) often do not possess a metapleural gland.

This hypothesis was challenged by Maschwitz (Maschwitz et al 1970, Maschwitz 1974). He was unable to experimentally demonstrate an enemy identification effect in the metapleural gland secretions, but he could show that in a number of ant species the metapleural gland secretions serve as powerful antiseptic substances that protect the body surface and nest against microorganisms. For example, the active antibiotic component of Atta sexdens was found to be phenylacetic acid, of which one ant stores an average of $1.4 \mu \mathrm{g}$ (Maschwitz et al 1970). In Crematogaster (Physocrema) difformis the secretions of the enlarged metapleural gland serve as antiseptics, but when discharged in larger quantities they can also repel animal enemies. Finally, in Crematogaster (Physocrema) inflata, which also possesses a hypertrophied metapleural gland, Maschwitz (1974) discovered that the sticky secretions function primarily as an alarmdefense substance. He hypothesized that in this case the antiseptic gland has evolved to become an alarm defense gland.

Our discovery of the atrophy of the metapleural gland among more genera than previously suspected places this organ in a new 

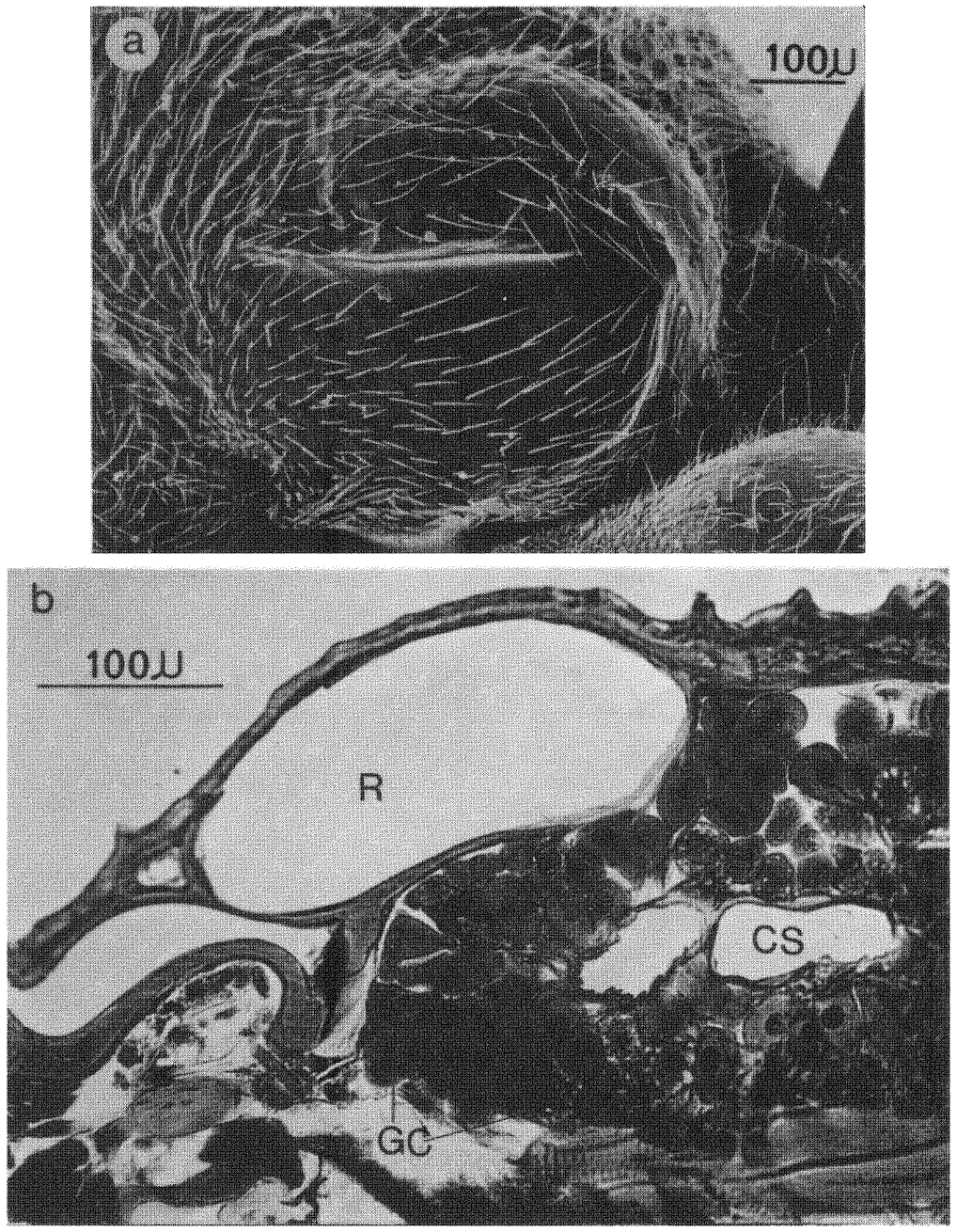

Fig. 2. Metapleural gland of a Nothomyrmecia macrops worker. a. SEM micrograph of meatus. b. Longitudinal section through the metapleural gland. CS $=$ collecting sac; $\mathrm{GC}=$ glandular cells; $\mathrm{R}=$ storage chamber. 

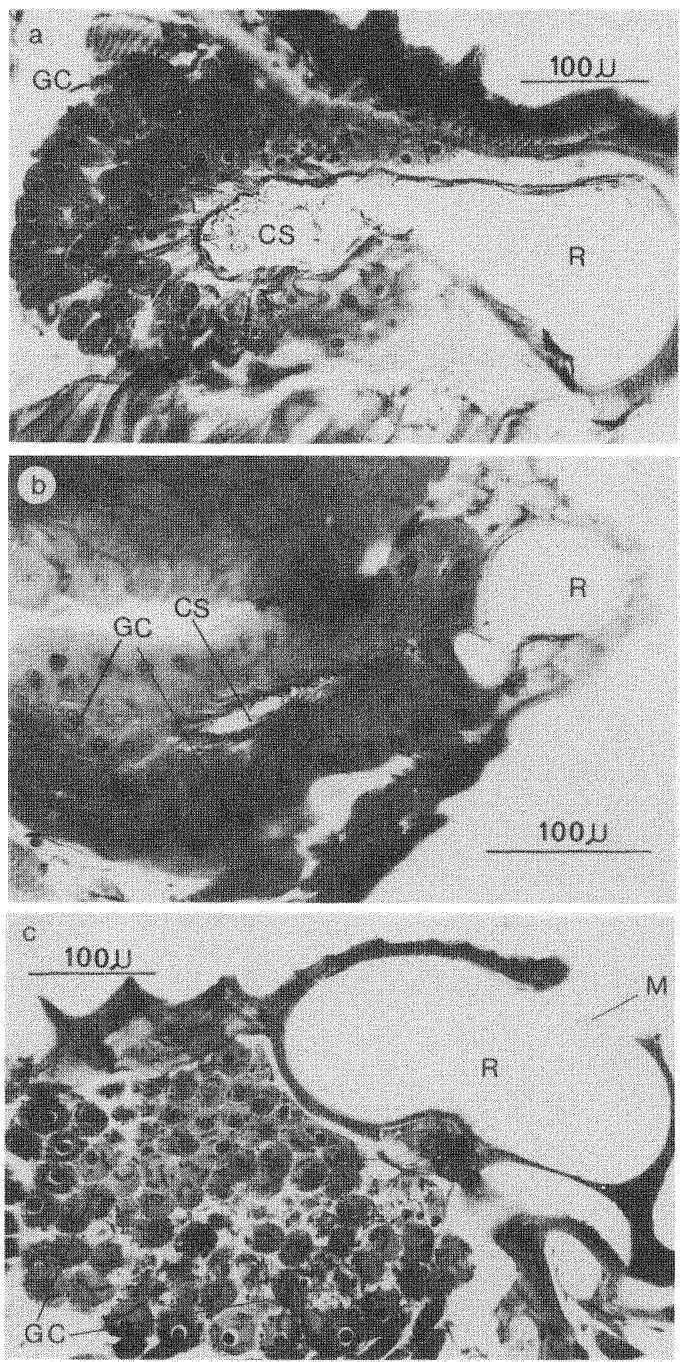

Fig. 3. (Above and facing page) Longitudinal sections through metapleural glands of workers of a. Myrmecia pilosula; b. Cerapachys? turneri; c. Rhytidoponera metallica; d. Pseudomyrmex pallidus; e. Novomessor albisetosus; f. Myrmecocystus mendax. $\mathrm{CS}=$ collecting sac; $\mathrm{GC}=$ glandular cells; $\mathrm{R}=$ storage chamber. 

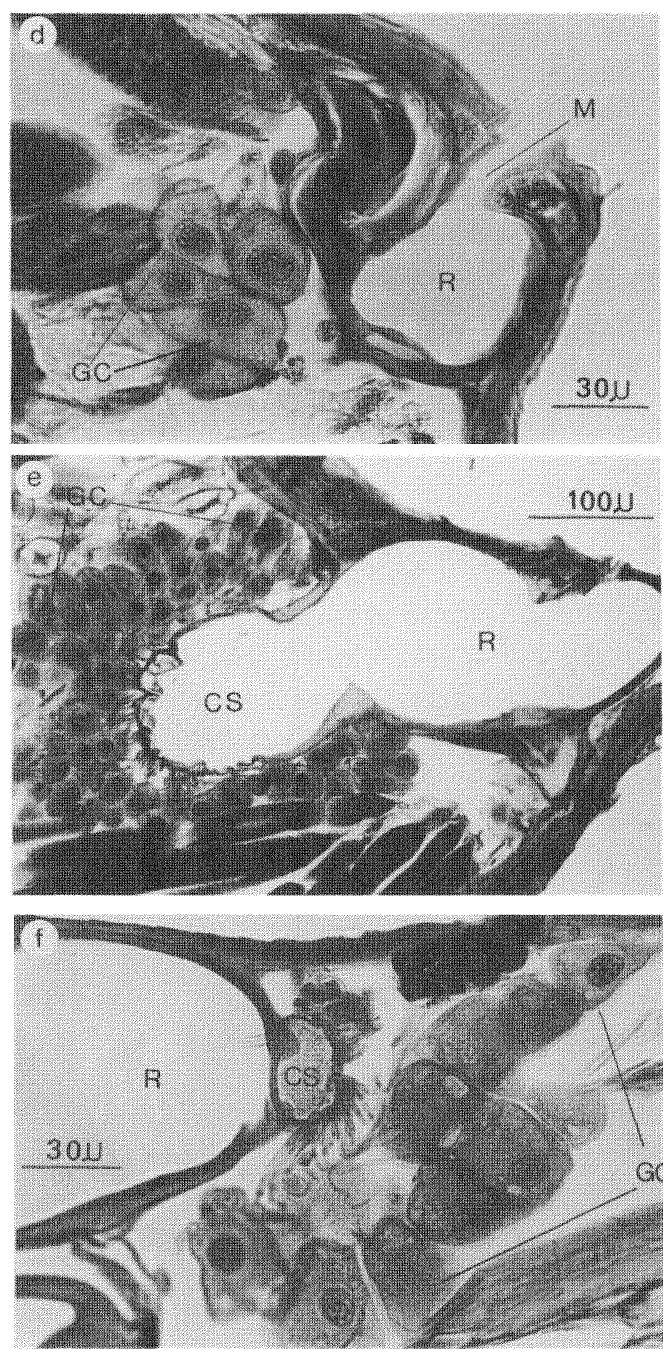
light. Since the gland is absent in a number of ant species known to be extremely aggressive and discriminatory towards conspecific foreigners and interspecific competitors (for Oecophy'lla see Hölldobler and Wilson 1978, Hölldobler 1979, 1984; for Camponotus see Carlin and Höldobler 1983) it is obvious that at least in these species the metapleural gland secretions have no function in enemy identification. The absence of the metapleural gland in male ants is also much more widespread than previously assumed. In fact, it appears that species in which males lack this organ or possess it in a very reduced state outnumber those in which the gland is well developed. Most of these males never have to enter a foreign colony in order to mate. Thus Brown's argument concerning the absence of the metapleural gland in doryline males is further weakened.

In our view Maschwitz's experimental evidence concerning the antiseptic effect of most metapleural gland secretions is very convincing. We have repeatedly heard the argument that the secretions of other pheromone glands, such as the mandibular gland or poison gland are also acidic and have the potential of suppressing the growth of Escherichia coli in test plates. Thus, it is argued that Maschwitz's tests, although demonstrating an antiseptic effect, do not necessarily prove a primarily antiseptic function of the metapleural gland. Maschwitz himself has pointed out that other exocrine glandular secretions frequently have antiseptic power. In fact, he hypothesized that most epidermal glands originally were antiseptic devices before they became more complex glandular structures that produce either repellent secretions against predators or alarm pheromones used in social communication (Maschwitz 1968, 1974; Maschwitz et al 1970).

Metapleural gland secretions can freely flow out of the storage chamber. The meatus is sometimes densely covered with bristles (Fig. 6), and often there are hairs and dispenser bristles inside the atrium along which the secretion can easily flow to the outer surface (Fig. 6c). As Brown (1968) pointed out, "some ant species have been seen to draw the legs, especially the tibia and tarsi of the forelegs, repeatedly over the meatus of the gland and then rub these leg parts over the rest of the body". In this way the metapleural gland secretion is probably spread over the whole body. It might also be distributed among nestmates by mutual grooming. Thus, it appears 

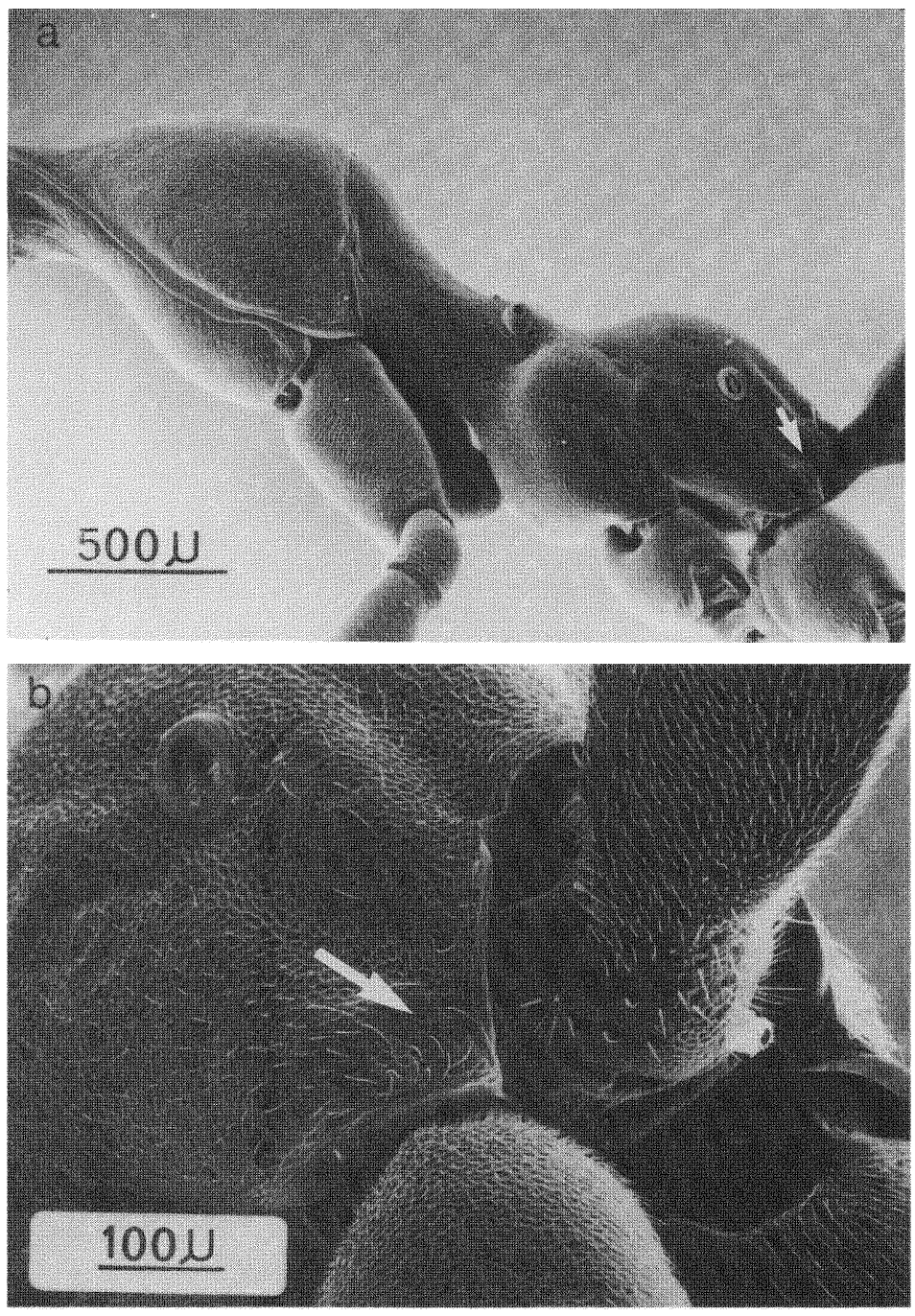

Fig. 4. a. SEM micrograph of the mesosoma of a worker of Oecophylla longinoda. b. Close-up of the posterolateral corners of the alitrunk. Arrows indicate the area where the opening of a metapleural gland should be located. 

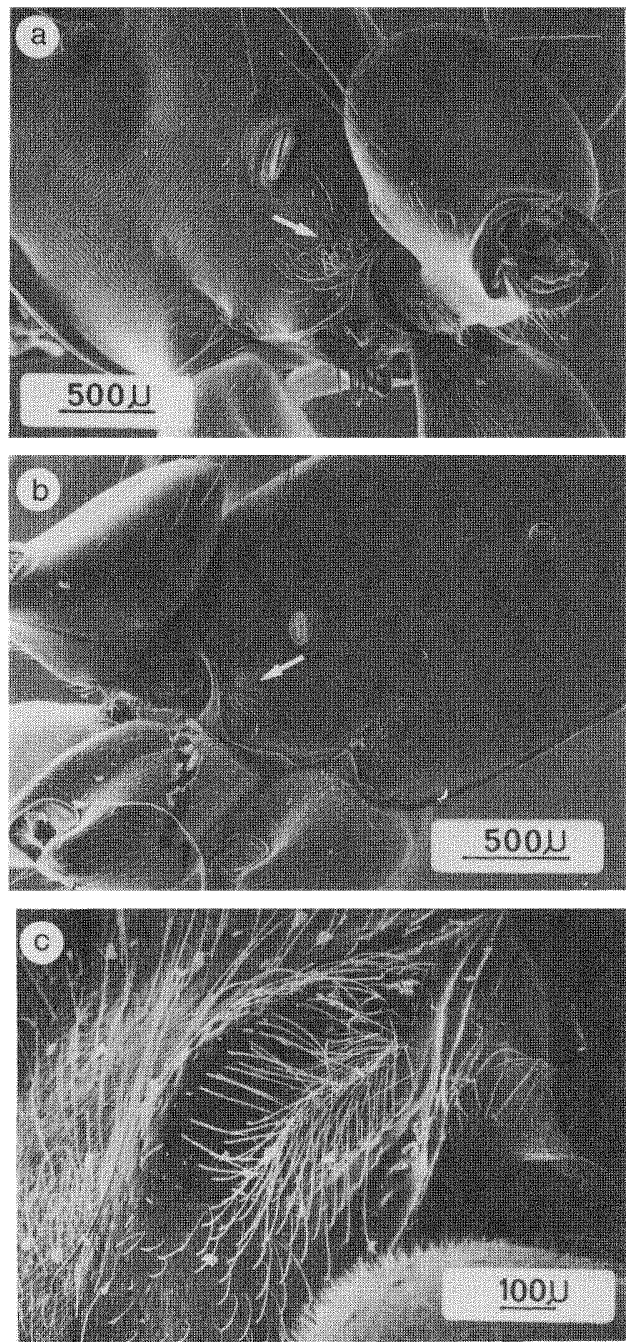

Fig. 5. (Above and facing page) SEM micrographs of the mesosoma of workers of several formicine species. Arrow indicates region where the opening of the metapleural gland should be located. a. Camponotus pennsylvanicus; b. Camponotus consobrinus. In both species there are clusters of hairs visible in the area of the metapleural gland opening. Both species, however, lack a slit-shaped opening. c. The slit-shaped opening of the metapleural gland of Camponotus gigas. No opening can be detected in d. Colobopsis truncata; e. Dendromyrmex chartifex; f. Polyrhachis (Cyrtomyrma)? doddi. 

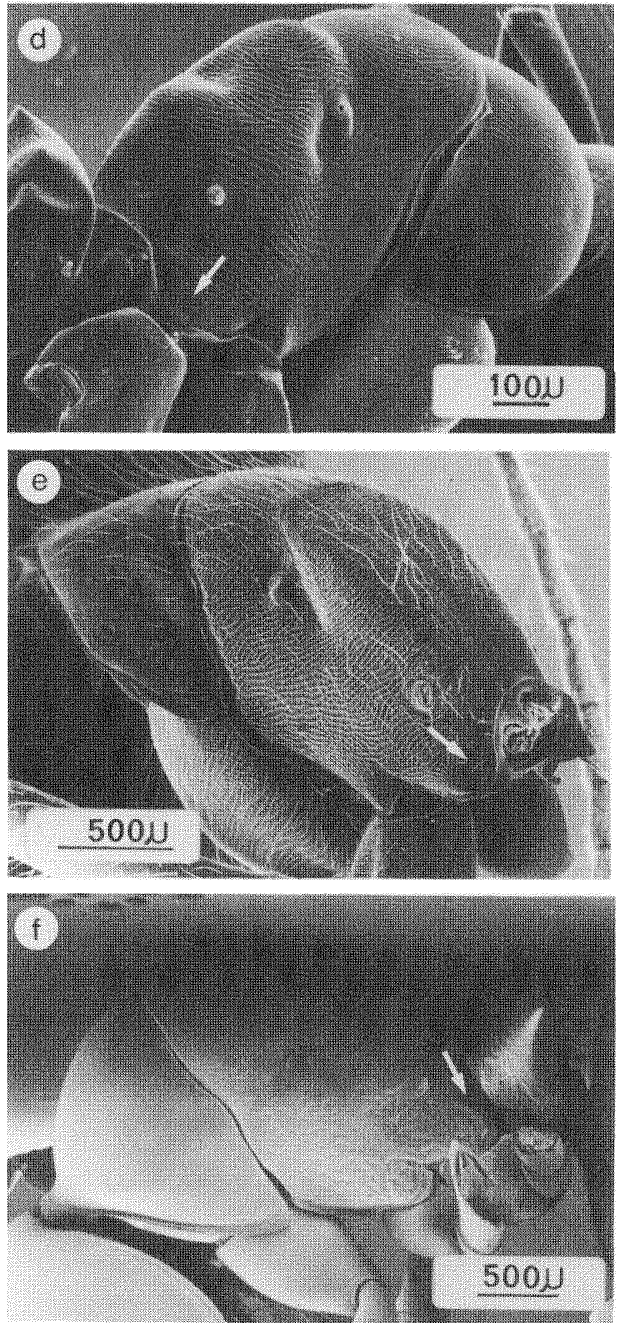
that the central location and general structure of the metapleural gland makes it ideally suited for distribution of an antiseptic secretion.

Why then is the metapleural gland absent or strongly atrophied in Oecophylla, Polyrhachis, Dendromyrmex, most Camponotus, certain social parasitic ants, and many male ants? Maschwitz et al (1970) offered the following explanations for the last two cases. Social parasitic ants, they argued, are usually highly attractive to the host ants, which groom them very frequently, so that the social parasites benefit from the social distribution of the antiseptic secretions of their host ants. This relieves the parasitic species of the burden of producing their own antiseptics and allows them to deploy the freed energy into other organs and functions. The absence of metapleural glands in male ants was given a different adaptive significance. Males live only a relatively short time inside the nest. They are also much less numerous than workers. Therefore, there exists no particular need for them to produce large amounts of antiseptic secretions.

The latter hypothesis, of course, raises the question why in some species the males do have relatively large metapleural glands (Fig. $7 \mathrm{f}$, Tab. 1). The reason could be that in those cases the ratio of males to workers might be much higher and/or the males might reside inside the nest for longer periods and therefore would present a considerable "antiseptic burden" to the colony. This would favor the selection of males capable of producing their own antiseptic secretions. Furthermore, the metapleural gland of male ants could also have another, secondary function, which does not exclude the primary antiseptic function; that is, it could produce sex pheromones and hence be an important character maintained by sexual selection. During mating females might thus favor males with well developed metapleural glands, and the capacity to produce larger quantities of pheromone.

It is interesting that in all weaver ant species studied the metapleural gland was atrophied. The species we checked included Oecophylla, Polyrhachis (Cyrtomyrma)? doddi, Dendromyrmex, Camponotus xenex. It is reasonable to speculate that these arboreal ants are much less exposed to microorganisms than terrestrial ant species, and therefore an antiseptic metapleural gland became unnecessary. 

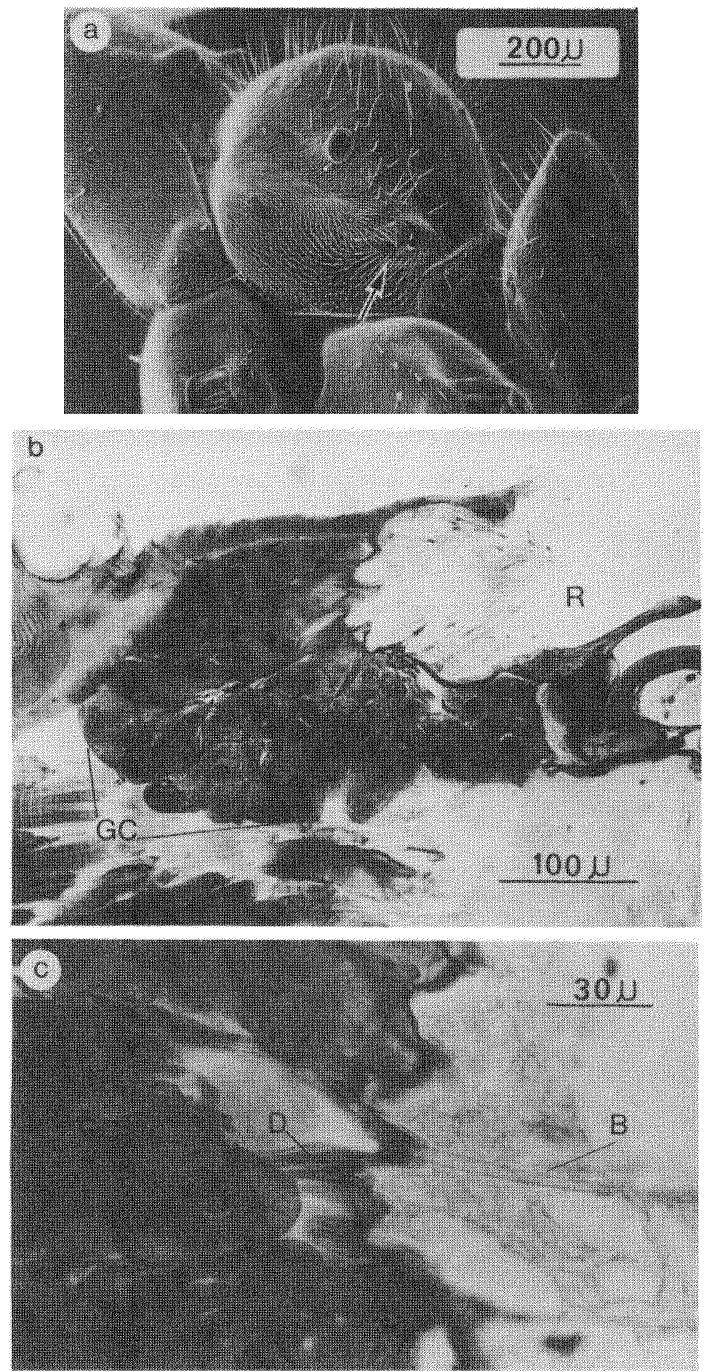

Fig. 6. The metapleural gland of a worker of Iridomyrmex purpureus a. SEM micrograph of mesosoma. The arrow points to the opening of the metapleural gland. b. Longitudinal section through the metapleural gland. c. Close-up of a section through the glandular cells (GC) and dispenser bristles (B); $D=$ glandular duct; $R=$ collecting chamber. 

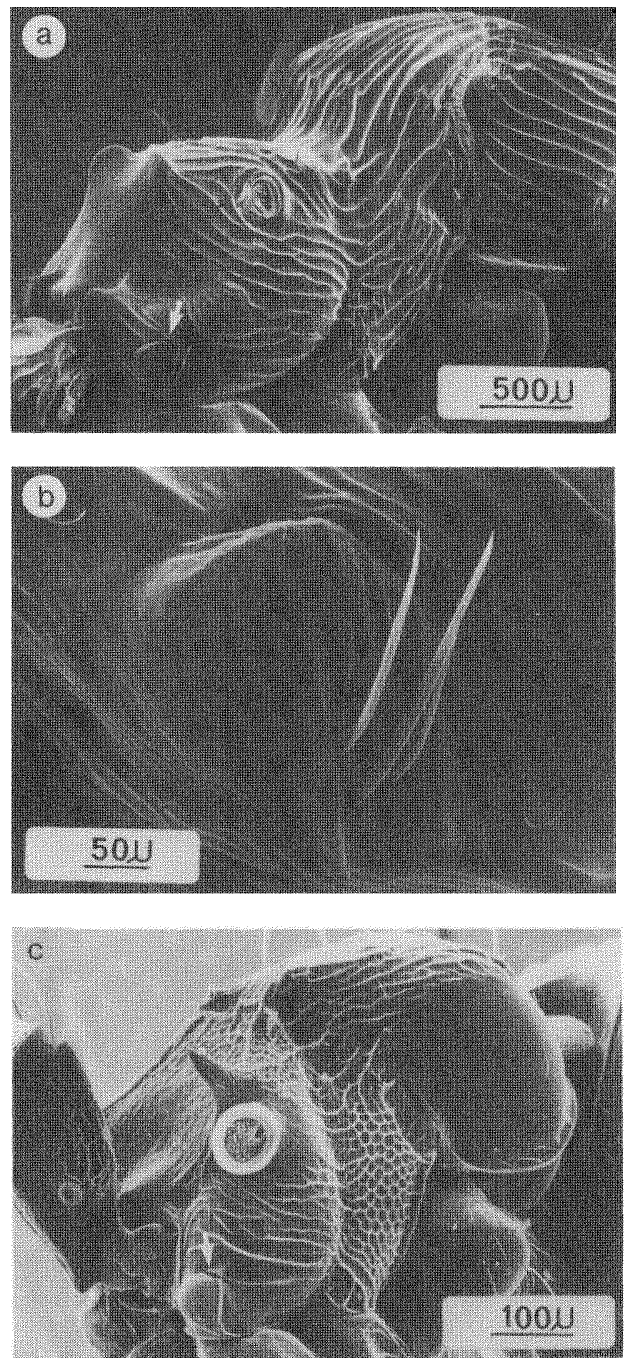

Fig. 7. (Above and facing page) SEM micrographs of the exterior structures of the metapleural glands of several ant species. a. Alitrunk of Podomyrma pulchra worker. b. Close-up of bulla, slit-shaped opening and sensory hairs (?) of the metapleural gland of $P$. pulchra worker. c. Alitrunk of Crematogaster sp 10 (ANIC) worker. d. Alitrunk of Catalacus intrudens worker. e. metapleural gland opening with sensory hairs (?) of $C$. intrudens worker. f. Alitrunk of Crematogaster sp 10 (ANIC) male. Arrows point to the opening of the metapleural gland. 

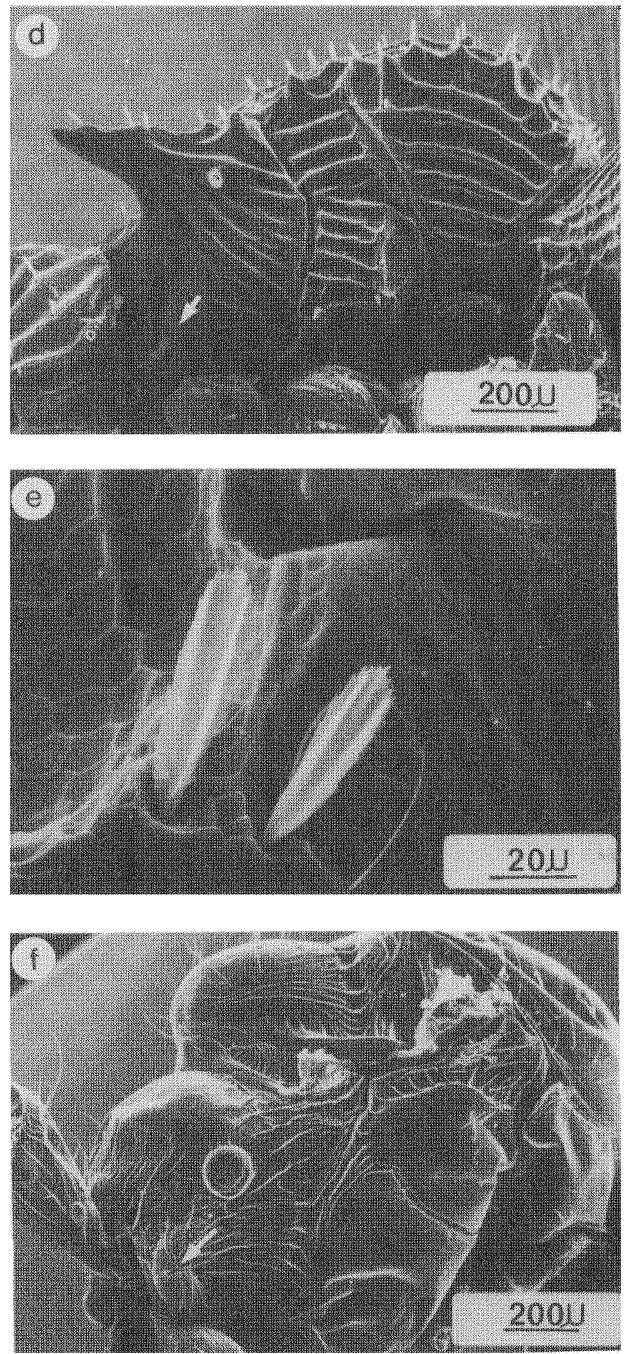


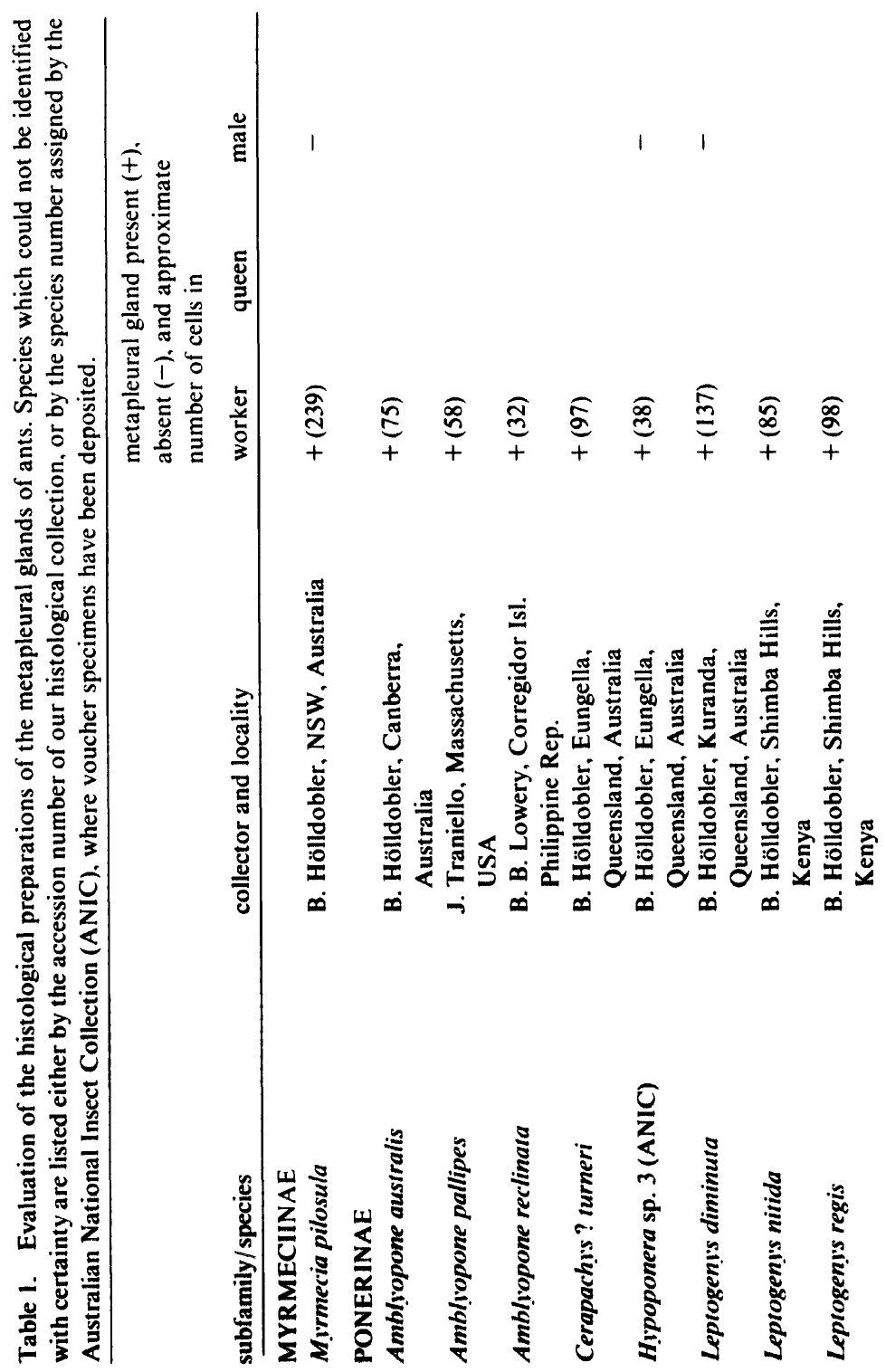


$\underset{+}{\widehat{\mathrm{s}}}$

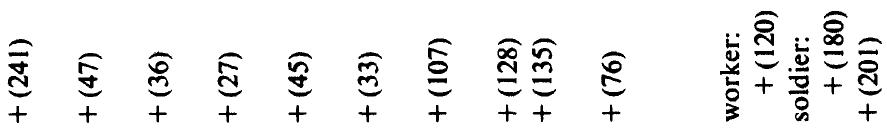
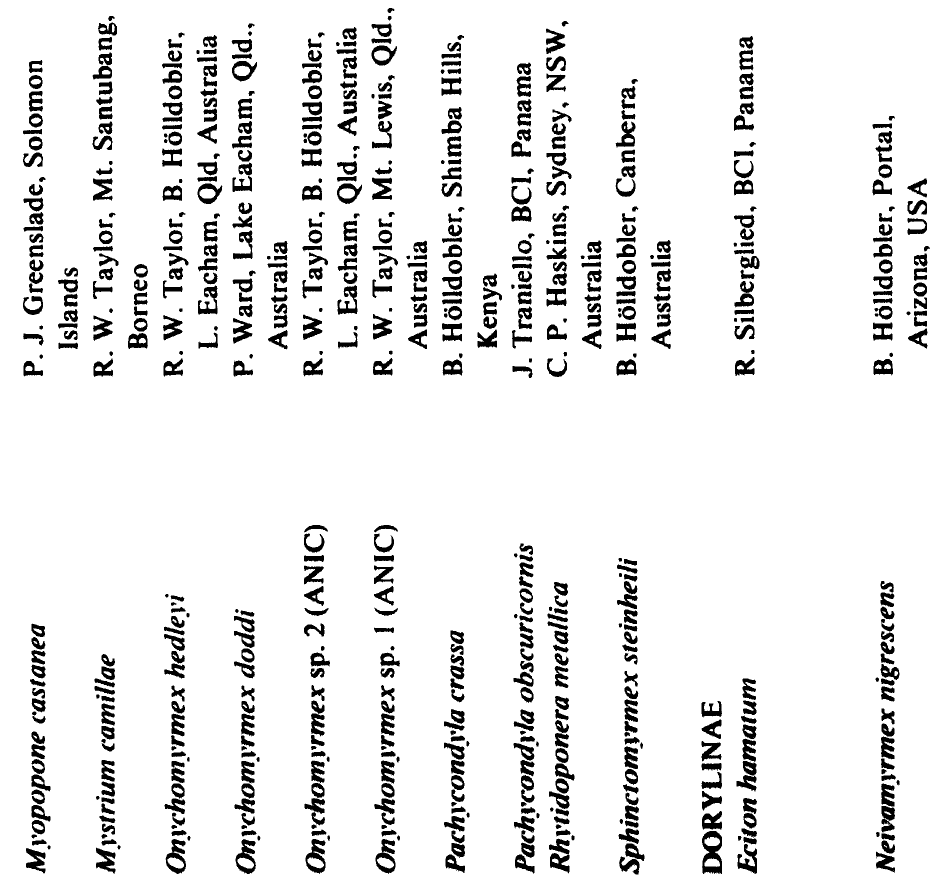


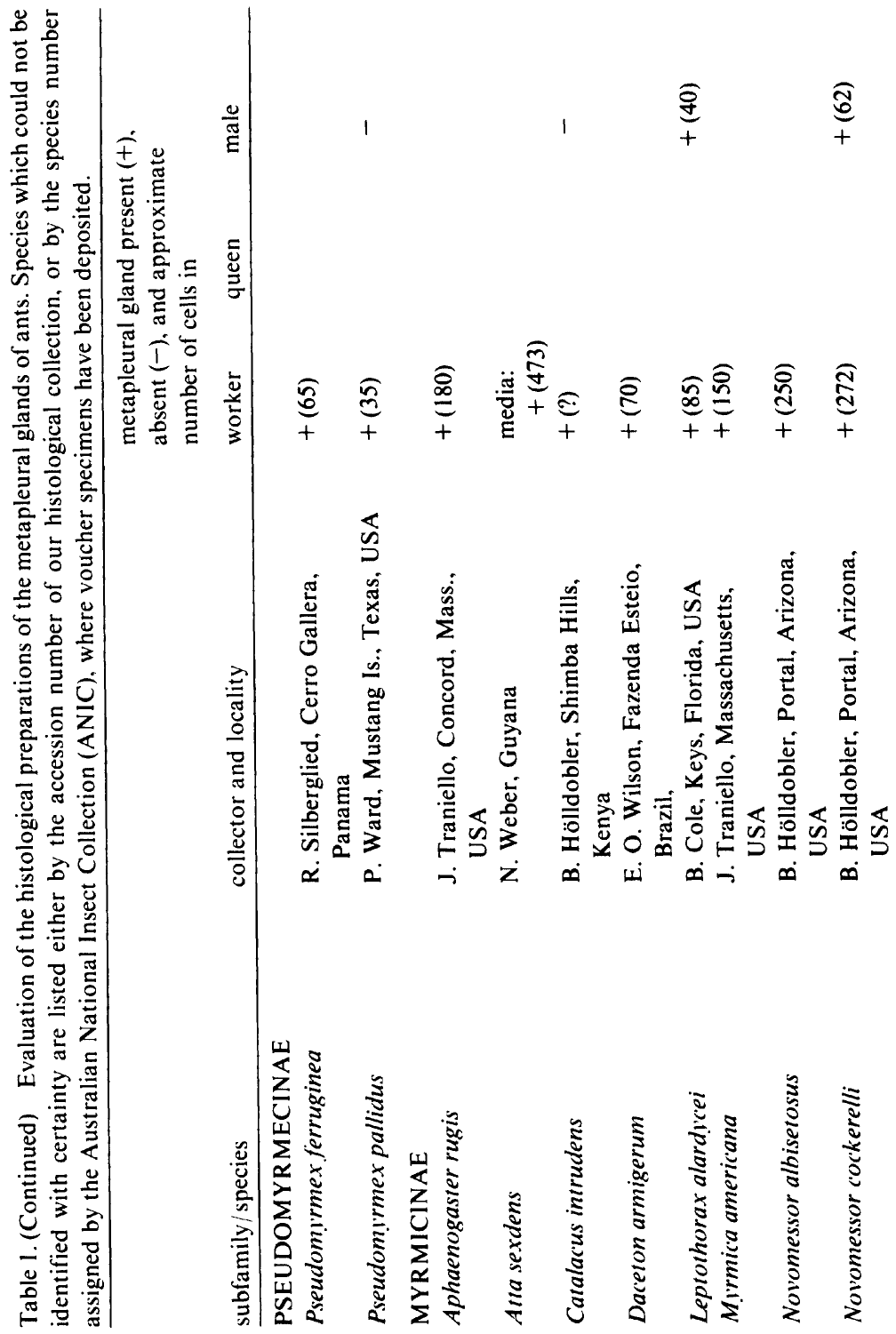




$$
\begin{aligned}
& \stackrel{\widehat{Q}}{+}
\end{aligned}
$$

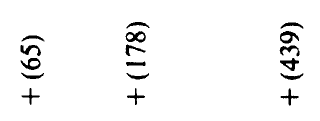

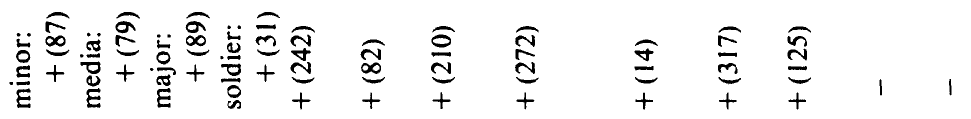

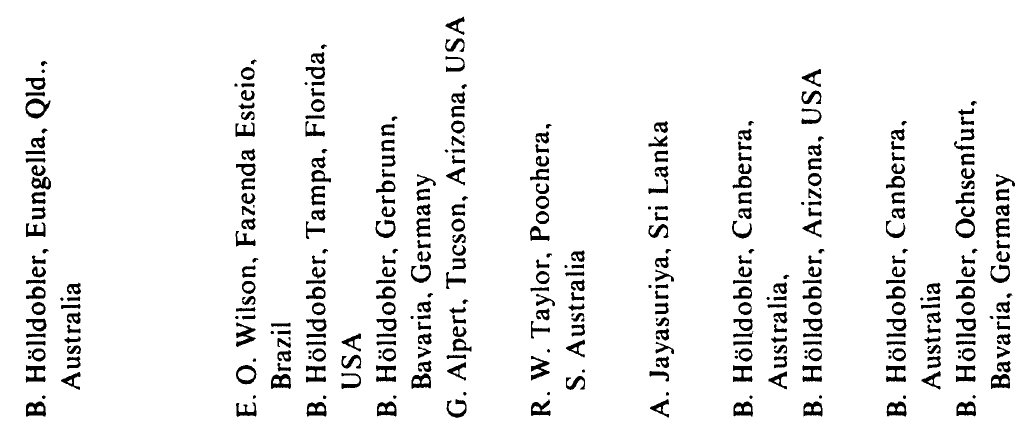

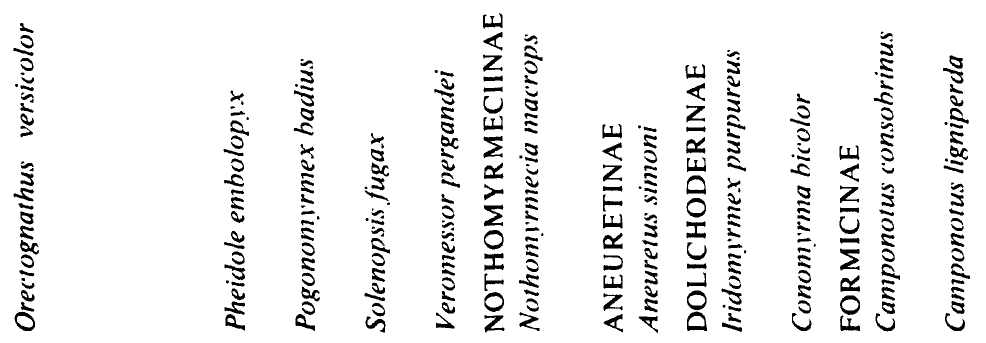




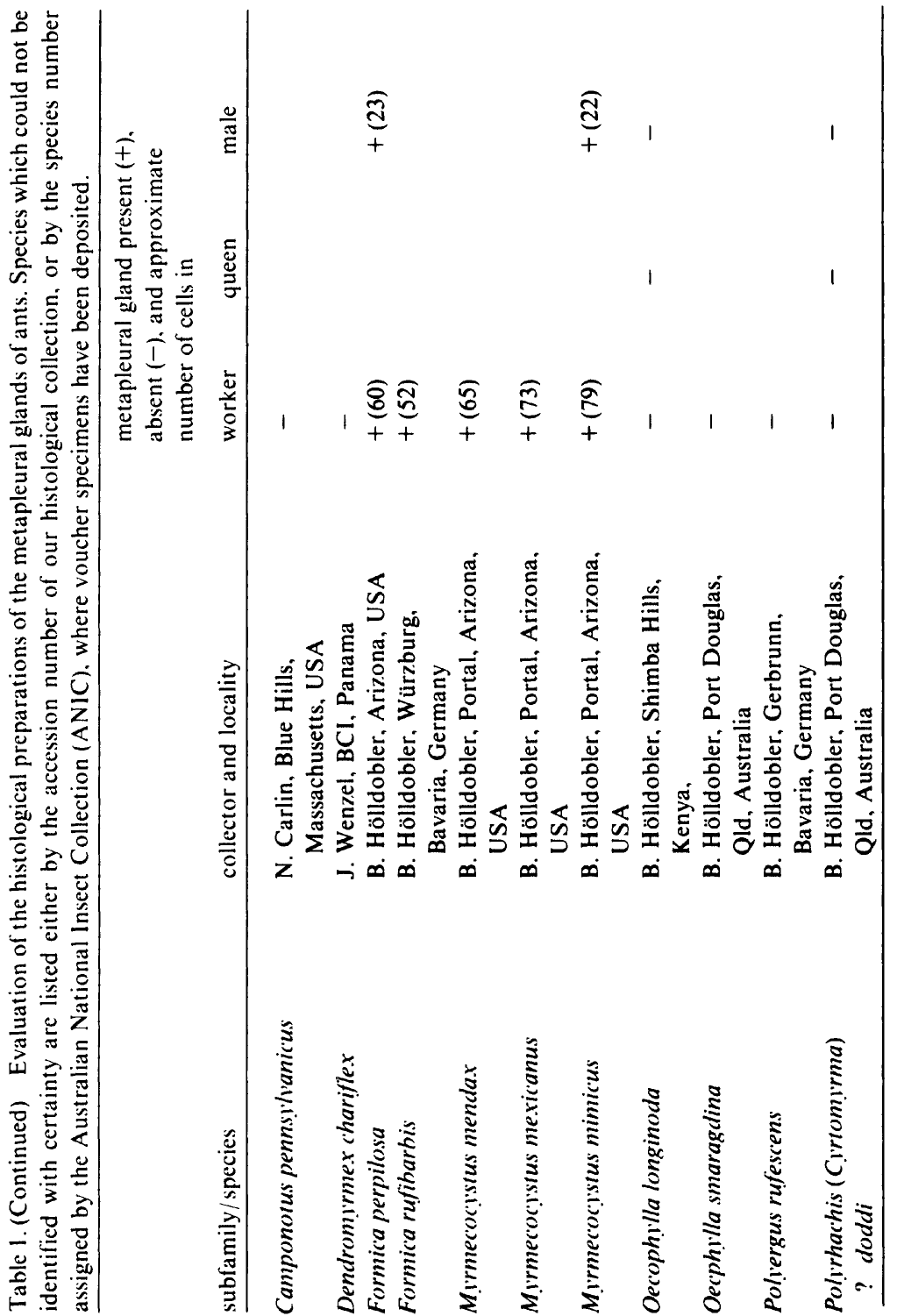


Table 2. An external survey of the presence $(+)$ or absence $(-)$ of features that indicate a metapleural gland in the genera Camponotus, Dendromyrmex, and Polyrhachis. Further information concerning species identification see Table 1.

\begin{tabular}{|c|c|c|}
\hline species & collector and locality & $\begin{array}{c}\text { metapleural } \\
\text { gland }\end{array}$ \\
\hline $\begin{array}{l}\text { Camponotus abdominalis } \\
\text { floridanus }\end{array}$ & $\begin{array}{l}\text { N. Carlin, Sugarloaf Key, Florida } \\
\text { USA }\end{array}$ & - \\
\hline $\begin{array}{l}\text { C. ? aeneopilosus } \\
\text { (sp. 3, ANIC) }\end{array}$ & B. Hölldobler, Canberra, Australia & - \\
\hline C. americanus & $\begin{array}{l}\text { N. Carlin, Blue Hills, } \\
\text { Massachusetts, USA }\end{array}$ & - \\
\hline C. castaneus & $\begin{array}{l}\text { P. Calabi, Tall Timbers, } \\
\text { Florida, USA }\end{array}$ & - \\
\hline $\begin{array}{l}\text { C. ? ephippium } \\
\text { (sp. 13, ANIC) }\end{array}$ & B. Hölldobler, Canberra, Australia & - \\
\hline C. ferrugineus & $\begin{array}{l}\text { N. Carlin, Blue Hills, } \\
\text { Massachusetts, USA }\end{array}$ & - \\
\hline C. gigas & $?$, S-Sumatra & + \\
\hline C. herculeanus & $\begin{array}{l}\text { B. Hölldobler, Gramschatz, } \\
\text { Bavaria, Germany }\end{array}$ & - \\
\hline $\begin{array}{l}\text { C. ? intrepidus } \\
\text { (sp. } 4 \text {, ANIC) }\end{array}$ & B. Hölldobler, Canberra, Australia & - \\
\hline C. midas (acc. \#190) & B. Hölldobler, Poochera, Australia & - \\
\hline C. nearcticus & $\begin{array}{l}\text { N. Carlin, Blue Hills, } \\
\text { Massachusetts, USA }\end{array}$ & - \\
\hline $\begin{array}{l}\text { C. ? nigriceps } \\
\text { (sp. 2, ANIC) }\end{array}$ & B. Hölldobler, Poochera, Australia & - \\
\hline C. perthiana & B. Hölldobler, Canberra, Australia & - \\
\hline C. planatus & B. Hölldobler, Keys, Florida, USA & - \\
\hline C. schaeferi & M. Möglich, Portal, Arizona, USA & - \\
\hline C. senex & $\begin{array}{l}\text { W. M. Wheeler, Pueblo Nuervo, } \\
\text { Panama }\end{array}$ & - \\
\hline C. sericeiventris & J. Traniello, BCI, Panama & - \\
\hline C. socius & B. Hölldobler, Tampa, Florida, USA & - \\
\hline $\begin{array}{l}\text { C. ? suffusus } \\
\text { (acc. } \# 236 \text { ) }\end{array}$ & B. Hölldobler, Canberra, Australia & - \\
\hline C. tortuganus & N. Carlin, Sugarloaf Key, Florida & - \\
\hline
\end{tabular}


Table 2. (Continued) An external survey of the presence $(+)$ or absence $(-)$ of features that indicate a metapleural gland in the genera Camponotus, Dendromyrmex, and Polyrhachis. Further information concerning species identification see Table 1.

\begin{tabular}{|c|c|c|}
\hline species & collector and locality & $\begin{array}{l}\text { metapleural } \\
\text { gland }\end{array}$ \\
\hline C. vicinus & $\begin{array}{l}\text { N. Carlin, N. Franks, Cortez, } \\
\text { Colorado, USA }\end{array}$ & - \\
\hline C. sp. 10 (ANIC) & $\begin{array}{l}\text { B. Hölldobler, Poochera, } \\
\text { S. Australia }\end{array}$ & - \\
\hline C. sp. 14 (ANIC) & B. Hölldobler, Canberra, Australia & - \\
\hline $\begin{array}{l}\text { C. sp. } 19 \text { (ANIC) } \\
\text { (walkeri group) }\end{array}$ & $\begin{array}{l}\text { B. Hölldobler, Cooktown, Qld, } \\
\text { Australia }\end{array}$ & - \\
\hline C. sp. 20 (ANIC) & B. Hölldobler, Canberra, Australia & - \\
\hline C. sp. 21 (ANIC) & B. Hölldobler, Kuranda, Australia & - \\
\hline $\begin{array}{l}\text { C. sp. } 22 \text { (ANIC) } \\
\text { (clareipes group) }\end{array}$ & $\begin{array}{l}\text { B. Hölldobler, Bateman's Bay, } \\
\text { NSW, Australia }\end{array}$ & - \\
\hline Dendrom!rmex fabricii & J. Wenzel, BCI, Panama & - \\
\hline $\begin{array}{l}\text { Polyrhachis? ammon } \\
\text { (acc. \#65) }\end{array}$ & $\begin{array}{l}\text { B. Hölldobler, Bateman's Bay, } \\
\text { NSW, Australia }\end{array}$ & - \\
\hline P. ? gab (acc. \#102) & $\begin{array}{l}\text { B. Hölldobler, Mt. Carbine, Qld, } \\
\text { Australia }\end{array}$ & - \\
\hline P. schlueteri & B. Hölldobler, Shimba Hills, Kenya & - \\
\hline $\begin{array}{l}\text { P. ? sokolova } \\
\text { (acc. \#95) }\end{array}$ & $\begin{array}{l}\text { B. Hölldobler, Port Douglas, Qld, } \\
\text { Australia }\end{array}$ & - \\
\hline P. sp. 2 (ANIC) & B. Hölldobler, Canberra, Australia & - \\
\hline P. sp. 3 (ANIC) & B. Hölldobler, Canberra, Australia & - \\
\hline
\end{tabular}

On the other hand other arboreal species, such as Pseudomyrmex, Podomyrma, Catalaucus (Fig. 7), Opisthopsis respiciens, and Lasius fuliginosus have well-developed metapleural glands, whereas some terrestrial Polyrhachis and Camponotus have lost their metapleural gland. But this does not contradict our speculation. An arboreal life style might favor but not necessitate a reduction and atrophy of the metapleural gland.* Furthermore, most Camponotus and Polyrhachis species are arboreal or live in or

\footnotetext{
*In a similar manner, the social parasitic life style appears to favor but does not necessitate the reduction of the metapleural gland (see Maschwitz et al 1970).
} 
on large pieces of dead wood. It is entirely possible that contemporary terrestrial species might have originiated from arboreal ancestors that had already lost their metapleural gland. We have currently no explanation, however, why Camponotus gigas appears to have retained or redeveloped its metapleural gland. Of course, it would also be interesting to known how those terrestrial species that have lost their metapleural gland defend themselves and their nests against microbial and fungal attacks.

\section{ACKNOWLEDGEMENTS}

We thank all the collectors mentioned in Table 1 and 2, and B. Bolton, W. L. Brown, R. Snelling, R. W. Taylor for helping us with the identification of many species, and Ed Seling for his assistance during the SEM work. Special thanks to R. W. Taylor and the Division of Entomology, CSIRO, Canberra (Australia) who in many ways supported this study. The work was further supported by grants from the National Science Foundation, the National Geographic Society and the John Simon Guggenheim Foundation.

\section{APPENDIX}

We would like to take this opportunity to correct some errors which appeared in two of our previous publications on exocrine glands in ants.

1) In our paper "Tergal and sternal glands in ants" (Psyche 85 , 285-330, 1978) on page 297, (Table 1a), Myrmecinae should be corrected to Myrmicinae; on page 298, the locality of Veromessor pergandei, given as Mexico, should be corrected to Arizona; on page 299, the species Pachycondyla spec. listed under the subfamily Formicinae should be corrected to Acantholepis spec.

2) In our paper "Tergal and sternal glands in male ants" (Psyche $89,113-132,1982$ ), Fig 1 B, the lettering PG should be changed to P, because it indicates part of the penis with the penis gland, and not the pygidial gland (PG), shown in Fig. 1A.

\section{REFERENCES}

Ayre, G. L. AND M. S. Blum. 1971 Attraction and alarm of ants (Camponotus spp.-Hymenoptera: Formicidae) by pheromones. Physiological Zoology 44: $77-83$. 
BRoWN, W. L. 1968. An hypothesis concerning the function of the metapleural glands in ants. Amer. Nat. 102: $188-191$.

CARlin, N. F. AND B. Holldobl.er. 1983. Nestmate and kin recognition in interspecific mixed colonies of ants. Science 222: 1027-1029.

HOI.L.DOBLIR, B. 1979. Territories of the African weaver ant (Oecophylla longinoda [Latreille]). A field study. Z. Tierpsychol. 51: 201-213.

Holl.dobl.t. B. 1983. Territorial behavior in the green tree ant (Oecophylla smaragdina). Biotropica, 15: $241-250$.

HOI.LDOBLER, B. AND E. O. WIISON. 1978. The multiple recruitment system in the African weaver ant Oecophylla longinoda (Latreille) (Hymenoptera: Formicidae). Behav. Ecol. Sociobiol. 3: 19-60.

Janit, CH. 1898. Etudes sur les Fourmis, les Guèpes et les Abeilles, Note 17: Système glandulaire tégumentaire de la Mirmica rubra. Observations diverses sur les Fourmis. Paris, George Carré et C. Naud, Editeurs, pp. 1-30.

K'RSCINik, I. 1970. Zur Anatomie von Formica pratensis, Retzius, 1783. Beitr. Ent. 20: 375-387.

LI'ввос' , J. 1877. On some points on the anatomy of ants. The Monthly microsc. Journal 18: 121 - 142.

Maschwitz, U. 1969. Wehrdrüsensysteme und Wehrverhalten bei Dytisciden. Verh. Dtsch. Zool. Ges. Insbruck (1968) Zool. An7. 32(suppl): 410-416.

Maschwitz. U. 1974. Vergleichende Untersuchungen zur Funktion der Ameisenmetathorakaldrüse. Oecologia 16: 303-310.

Maschitit, U., K. KoOB INA H. SCHILdknecht, 1970. Ein Beitrag 7ur Funktion der Metapleuraldrüse der Ameisen. J. Ins. Physiol. 16: 387-404.

Misiert, F. 1860. Bidrag til de danske Myrers Naturhistorie. Dansk Vetensk. Selskab. 5: 275 - 340 .

TAYior, R. W. 1978. Nothomirmecia macrops: a living-fossil ant rediscovered. Science 201: $979-985$.

Tilı.сн, G. S. 1936. The metasternal glands of the ant Mirmica rubra, with special reference to the golgi bodies and the intracellular canaliculi. Ann. Entomol. Soc. Amer. 29: 81-84.

Tilio(ii, G. S., J. E. Shapiro, and B. Hershinov. 1962. The ultrastructure of the metasternal glands of ants. Brooklyn Entomol. Soc. Bull. 77: 91-101.

Whilden, R. M. 1957a. Notes on the anatomy of the Formicidae I. Stigmatomma pallipes (Haldeman). J. New York Ent. Soc. 65: 1-21.

Whitdin, R. M. 1957b. Notes on the anatomy of Rhytidoponera convexa Mayr ("violacea" Forel) (Hymenoptera: Formicidae). Ann. Ent. Soc. Amer. 50: $271-282$.

Wintidis. R. M. 1960. The anatomy of Rh!tidoponera metallica F. Smith (Hymenoptera: Formicidae). Ann. Ent. Soc. Amer. 53: 793-808.

WHELDEN, R. M. 1963. The anatomy of the adult queen and workers of the army ants Eciton hurchelli Westwood and Eciton hamatum Fabricius. J. New York Ent. Soc. 71: 90-115.

Wil.son, E. O., F. M. Carpenter ANd W. L. Brown. 1967a. The first Mesozoic ants, with the description of a new subfamily. Psyche (Cambridge) 74: 1-19.

Wilson. E. O., F. M. Carpenter and W. L. Brown. 1967b. The first Mesozoic ants. Science 157: 1038-1040. 

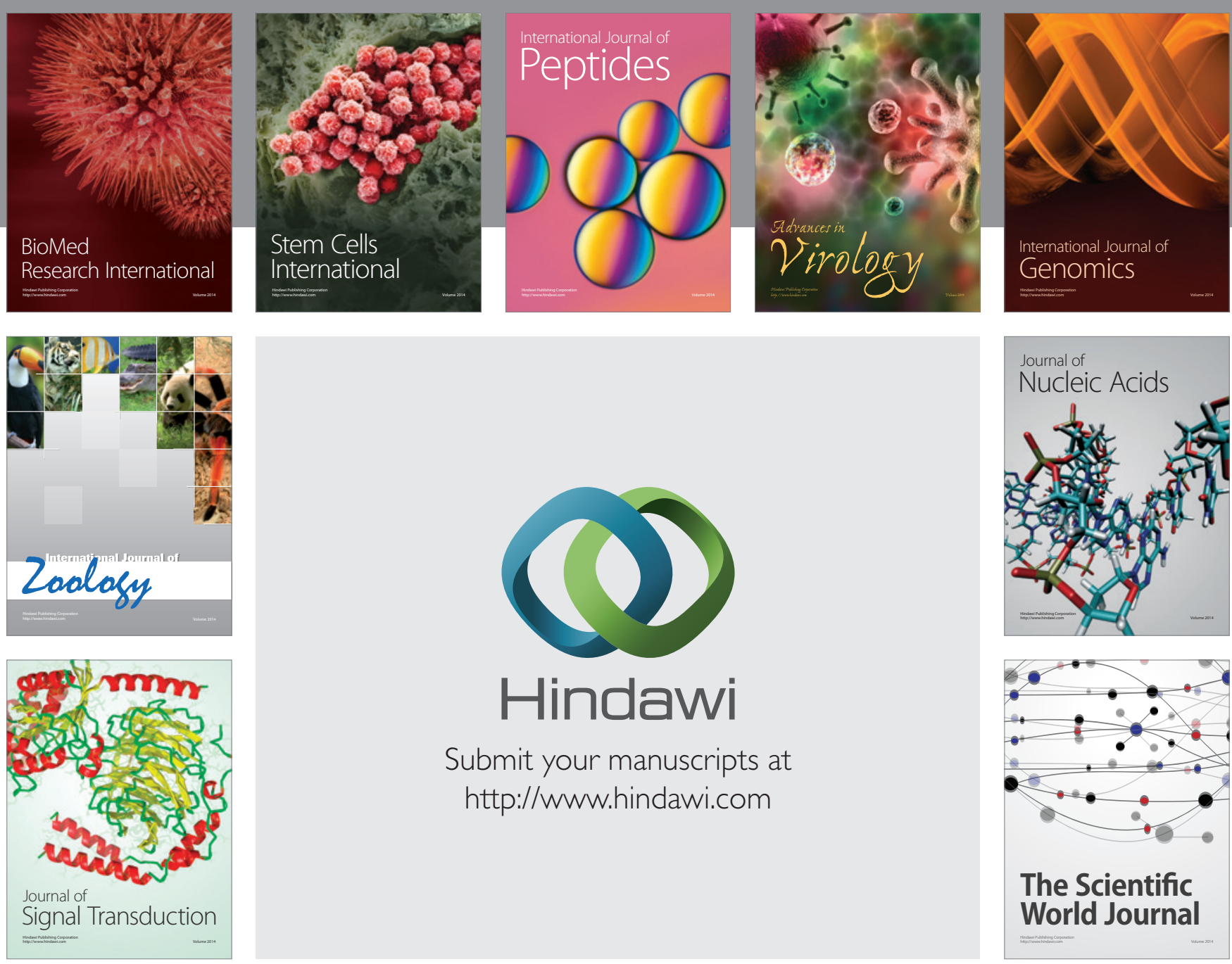

Submit your manuscripts at

http://www.hindawi.com
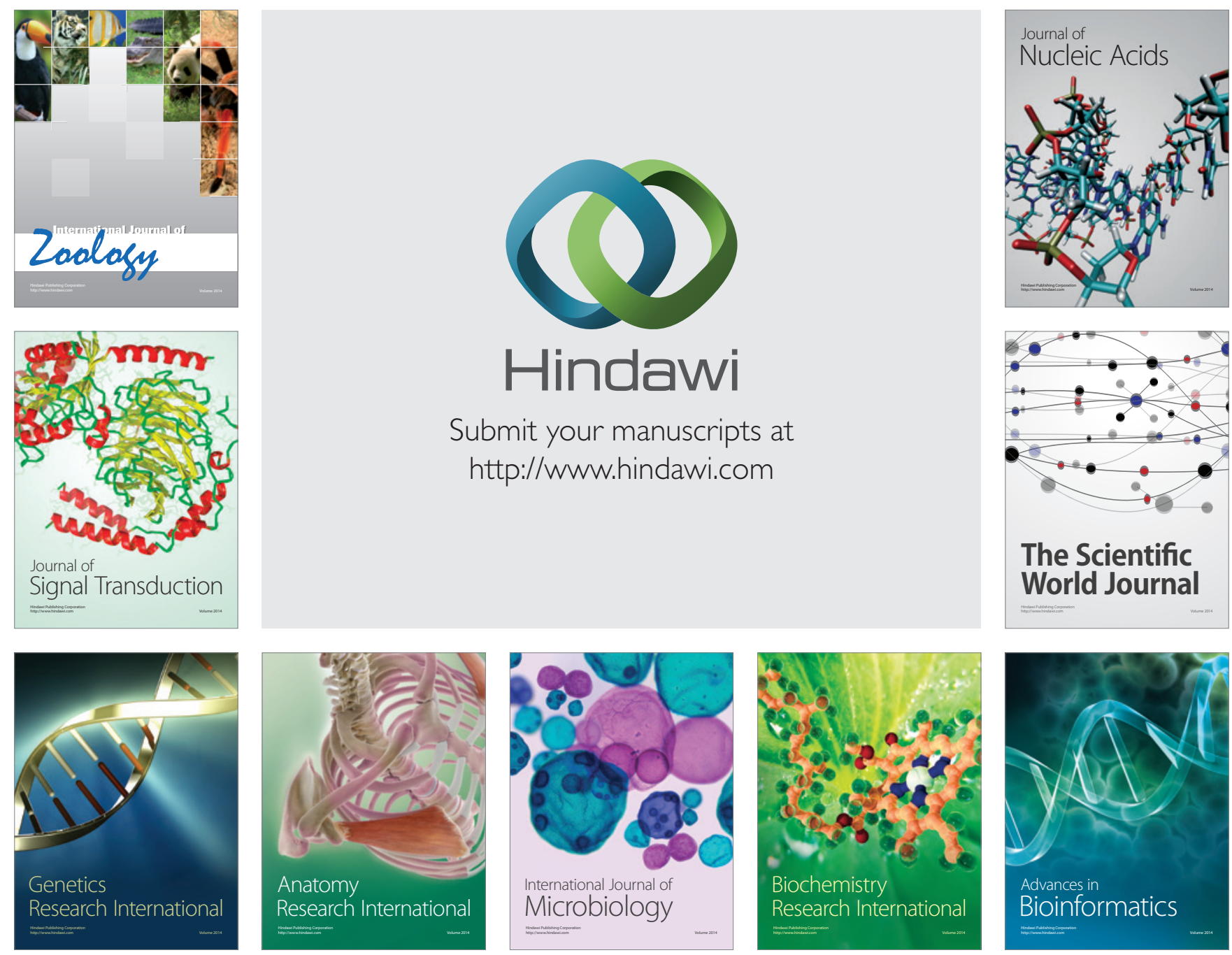

The Scientific World Journal
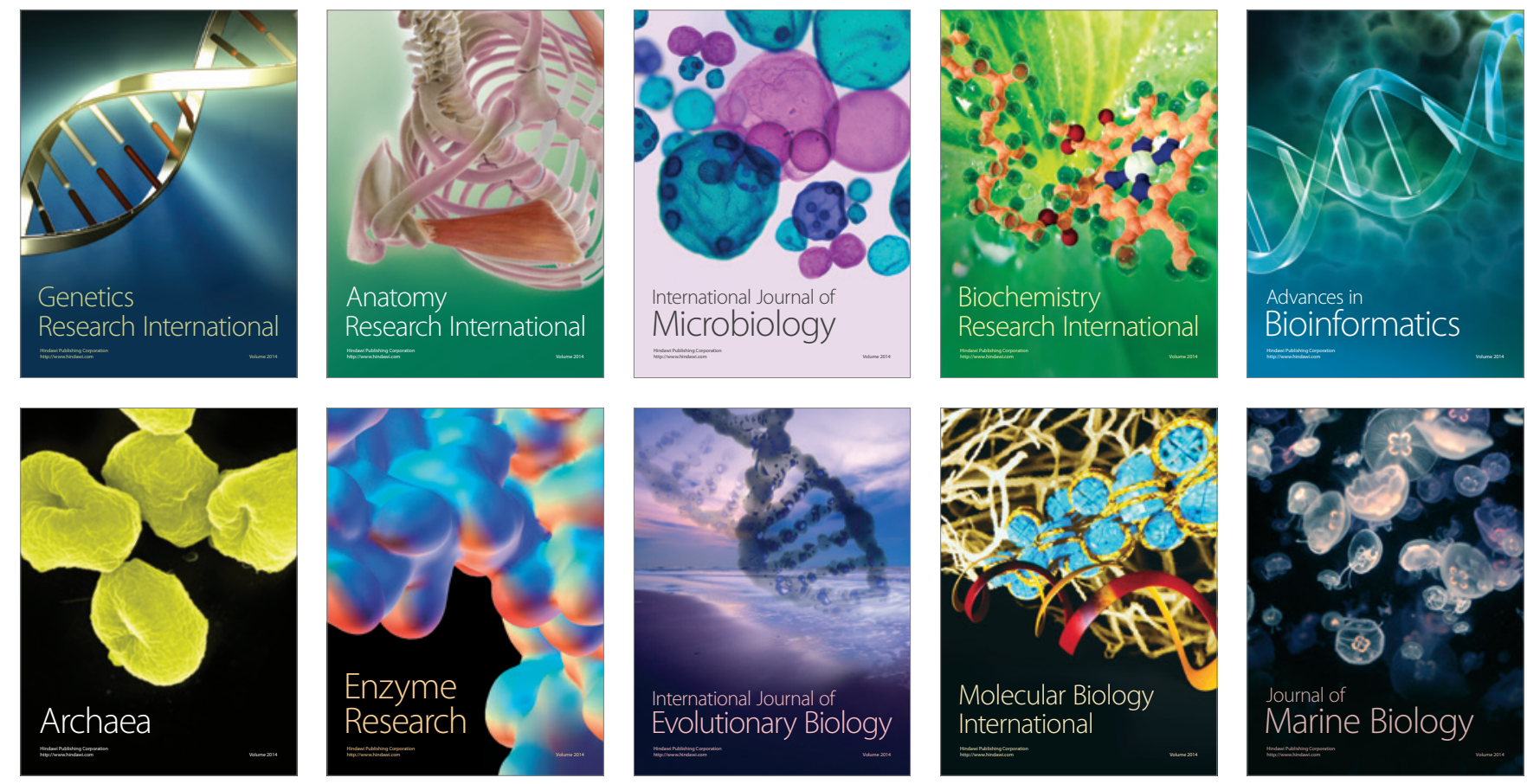